Article

\title{
The Civil Society Dynamic of Including and Empowering Refugees in Canada's Urban Centres
}

\author{
Oliver Schmidtke \\ Department of Political Science, University of Victoria, Victoria, BC V8P 5C2, Canada; E-Mail: ofs@uvic.ca
}

Submitted: 6 December 2017 | Accepted: 23 February 2018 | Published: 29 March 2018

\begin{abstract}
This article addresses the critical role that civil society at the urban level plays in integrating and empowering immigrants and minorities in Canadian society. From a place-based approach, it investigates how key agencies in the local community have been instrumental in including immigrants in general and refugees in particular into the fabric of Canadian society. Empirically the analysis focuses on Neighbourhood Houses in Greater Vancouver and the Privately-Sponsored Refugee program in Canada. With the interpretative lens on the urban context, the article shows how immigrants and refugees have gained agency and voice in the public arena through place-based communities. The insight into these two empirical cases provides the basis for conceptualizing the socio-political dynamics of immigrant settlement and integration in terms of the effects generated by urban governance structures.
\end{abstract}

\section{Keywords}

Canada; civil society; immigration; integration; refugees

\section{Issue}

This article is part of the issue "The Transformative Forces of Migration: Refugees and the Re-Configuration of Migration Societies", edited by Ulrike Hamann and Gökçe Yurdakul (Humboldt University of Berlin, Germany).

(C) 2018 by the author; licensee Cogitatio (Lisbon, Portugal). This article is licensed under a Creative Commons Attribution 4.0 International License (CC BY).

\section{Introduction: Place-Based Approaches to Integration}

In public and scholarly debate, the meaning of integration is controversial with respect to both its underlying conceptual-normative understanding and its implications for policy-making. At first sight, there is a considerable degree of consensus among scholars, policy-makers and the public at large that the full, equitable and fair 'integration' into the fabric of society is the desirable outcome for immigrants. Yet, the very concept of integration is challenging to define and implement (e.g., Ager \& Strang, 2008; Esser, 2010). Integration seeks to describe how a successful process of-to use less contested terms-inclusion or incorporation of migrants ought to unfold and where it is supposed to lead: Is success in the labor market or the education system a sufficient criterion for accomplished integration? To what extent does successful integration require the adoption of the culture and values of the host society? The concept of integration generally seeks to describe a neutral process of socio-structural and political "inclusion" (e.g., Freeman,
2004; Habermas, 1996). However, the social and political meaning of integration is contested, in particular regarding the underlying notion of cultural belonging. In addition to the complex reality that this concept claims to describe, 'integration' has become the vehicle for often normatively-backed expectations about the relationship between immigrants and the host society.

In the scholarly debate, there have been two approaches aimed at arriving at an empirically more accurate conceptualization of immigrant integration. First, recent scholarship has started to question the disproportionate focus on national models and accommodation of diversity that research on the integration of immigrants has traditionally adopted (e.g., Entzinger \& Biezeveld, 2003; Jacobs \& Rea, 2007; Parekh, 2006). The supra- as well as the sub-national levels of governance have become meaningful arenas in which integration is addressed in terms of policy development and integration outcomes (e.g., Bloemraad, Korteweg, \& Yurdakul, 2008; Erdal \& Oeppen, 2013). At its core, integration is a place-based practice that is shaped by territorially specific social, po- 
litical and cultural environments (e.g., Bradford, 2005). Most importantly, research on the role of the local context has underlined that integration processes are essentially rooted in communal practices and forms of urban or regional citizenship (e.g., Hepburn, 2011; Penninx, Kraal, Martiniello, \& Vertovec, 2004). The local and regional contexts provide a central arena for how the need for integration is translated into concrete programs and how successful these initiatives are (e.g., Bertossi \& Duyvendak, 2012; Leo \& August, 2009; Duyvendak \& Scholten, 2011; Schmidtke, 2014; Siemiatycki, 2012; Tossutti, 2012).

Second, the politics of integration has received notable scholarly attention, shedding light on the structural power imbalances in defining the normative expectations and societal practices of integration. Can and should immigrant integration simply be understood as a statesanctioned practice in which those who are expected to live up to its expectations have no voice? In particular, the European context provides ample evidence of how the state-centred request for 'integration' can be employed as a vehicle for demanding assimilation and reproducing exclusion (e.g., Brubaker, 2001; Joppke \& Morawska, 2014; Li, 2003). In this respect, integration is regularly based on unspecific expectations and cultural norms that immigrants deem impossible or undesirable to meet. Immigrants and minorities find themselves as objects of integration requests rather than as subjects in the process of co-determining their meaning and socio-political practice. The result can be paradoxical: The very term that is meant to guide the way for equitable and fair social inclusion becomes a device for reproducing social and symbolic exclusion (e.g., Joppke, 2007; Triadafilopoulos, 2011).

This article starts from the theoretical assumption that successful integration of immigrants and minorities is critically dependent on providing them with opportunities to be meaningfully included in public debate and policy-making. The focus of this investigation into the civil society dynamic of including refugees and migrants is guided by a place-based approach. In a first step, I will depict how the Canadian legacy of promoting the integration of its immigrant population has opened new opportunities for negotiating social and political inclusion through civil society governance structures. This claim will then be substantiated by two brief analyses of community-based engagement. The first relates to Neighbourhood Houses (NHs) in Greater Vancouver and the role they play in providing modes of effective integration and an entry point for public engagement to immigrants and minorities. The second investigates the dynamic generated by Canada's privately sponsored refugee program with a focus on its broader sociopolitical implications.

\section{The Effects of Canadian Integration and Multicultural Policies on the Ground}

Over the past fifty years, Canadian society has been shaped by the transformative impact of migrants in fun- damental ways. This dynamic is critically associated with a far-reaching policy shift in the late 1960s and early 1970s, namely the introduction of a point-based immigration policy (resulting in high and sustained levels of immigrant recruitment), the expansion of integration policies, and the introduction of multiculturalism as a mode of governing the increasing cultural diversity of Canadian society. Over the past five decades, this commitment to publicly supporting diversity and to equitable opportunities for newcomers has guided policy-making and, from a broader societal perspective, the expectation of what successful integration means in practice. In this respect, the multicultural ethos of the Canadian immigrant regime is also based on the promise of equitable social inclusion and the commitment to fighting discrimination (e.g., Triadafilopoulos, 2012).

At the same time, and this will be the focus of the subsequent analysis, with its immigration, integration, and multicultural policies, Canada has embarked on a path to empowering immigrants and refugees in civil society. In the Canadian context, it is striking to see how advocacy groups representing different immigrant communities have become an articulate and influential voice in the public arena. The decentralization of settlement services and the partnership with community organizations in delivering them has-regardless of severe cuts to the funding of settlement associations over the past years-provided an opportunity for active engagement in governing integration on the ground. Immigrant and settlement organizations have become critical stakeholders in urban governance structures: They have intimate knowledge of integration challenges in the community, interact regularly with municipal authorities in program development, and are of critical importance for program implementation (see for a case study of immigrant integration in the health sector: Falge, Ruzza, \& Schmidtke, 2012).

According to a Citizenship and Immigration Canada report from 2001, integration requires the active participation of both the newcomer and citizens of the host country; "rather than expecting newcomers to abandon their own cultural heritage, the emphasis is on finding ways to integrate differences in a pluralistic society" (Citizenship and Immigration Canada, 2001, p. 4). I interpret the successful societal integration and political inclusion as mutually reinforcing processes. In this respect, statecentred settlement and integration policies have set in motion a dynamic in civil society that has had effects far beyond what was initially intended by some of the state-orchestrated, top-down initiatives (e.g., Hiebert \& Sherrell, 2009).

The federal policy on multiculturalism has also had an impact on the mobilization of ethnocultural communities. Particularly in the period after the 1970s and 1980s, federal multiculturalism policy was intended to increase the capacity of immigrant communities to take collective responsibility for dealing with the causes of inequality and for developing mobilization strategies, including ju- 
dicial recourse, in order for newcomers and minorities to be able to exercise their rights at all levels of government (e.g., Bradford, 2005). The activity of civil society groups has contributed to making diversity and cultural pluralism principal issues in public debate and, from a normative perspective, principles endorsed in Canadian society and politics. In this regard, multiculturalism no longer merely celebrates folkloristic differences but has also evolved to address matters of power-sharing with some of the critical challenges facing Canadian society for instance regarding modes of governing diversity and addressing inequality (e.g., Siemiatycki, 2012). What we can observe in the Canadian context is a self-reinforcing cycle of ethnocultural mobilization and political responsiveness within the political system-a cycle decisively driven by civil society organizations in urban contexts.

This dynamic is also structurally sustained by decentralizing and outsourcing settlement services to community organizations as part of Canada's integration policies (e.g., Stasiulis, Hughes, \& Amery, 2011). Beyond merely attending to these tasks as administrative agencies, civil society organizations have also taken on the role of political advocates for migrants, for minorities, and as influential agents in developing integration programs on the ground. The formation of integration policies at the local level is driven by a broader governance network, of which migrants' and minorities' organized interests have become a constitutive part (e.g., Hiebert \& Sherrell, 2009). As Ley observes:

Bringing mainstream civil society closer to immigrant everyday life, these programs are delivered not by bureaucrats but by nongovernmental organizations (NGOs) with co-ethnic staff, and provide not only services but also jobs and volunteer positions to recent arrivals. The intent here is to create bridging social capital with immigrant groups through their NGOs and thereby aid the integration process. (Ley, 2007, p. 186)

At the same time, this community-based engagement unfolds in particular institutional and political-discursive contexts. It is worth highlighting that there are considerable differences in this respect between big urban centres, with well-organized migrant organizations, and smaller cities. In the latter, the task of representing these groups' interests and acting as agents of political advocacy is constrained by a limited number of settlement agencies and the relative absence or weakness of smaller ethnocultural community groups. Traditionally, political advocacy and (at least partial) access to the decision-making process in policy formation was afforded to those organizations that provided settlement services in the community.

\section{NHs in Greater Vancouver-Place-Based Governance: The Role of Civil Society Organizations}

The context of Greater Vancouver and the role that NHs have as place-based, community-governed, and nonprofit organizations, provides a pertinent illustration for the dynamic of promoting migrants' and minorities' societal inclusion and political empowerment. NHs have a long-standing history in the Vancouver context dating back to 1938 and have traditionally served less privileged groups with a variety of social services. The central role of $\mathrm{NHs}$ is to work towards greater social cohesion and inclusiveness through grass-root initiatives. There are 14 such NHs across Metro Vancouver, which are united by the core mission of helping to build welcoming and inclusive communities at the neighbourhood level. Over the past two decades, NHs have taken on a pronounced role in supporting the settlement and inclusion of newcomers, providing them with access to the community.

In a multi-year study focusing on Greater Vancouver, ${ }^{1}$ we investigated to what degree $\mathrm{NH}$ s provide the leadership role in building local community capacity for promoting integration and addressing social exclusion. The most straightforward way in which $\mathrm{NHs}$ have contributed to this agenda is through the scope and nature of the community services they provide. In 2013, $\mathrm{NHs}$ in Metro Vancouver provided a total of 444 programs/activities. In total, 208,664 participants took part in these activities many of which catered to newcomers providing low-barrier and affordable access to services in the community (employment support, daycare, afterschool care, senior day activities, parent groups, recreational programs, sociocultural events, youth leadership, and more). NHs are part of the broader infrastructure of settlement providers. In this capacity, they play an essential role in addressing social isolation and the lack of social capital as impediments to successful integration (Yan, 2004; Yan \& Lauer, 2008).

One key element of this research was a survey among users of services and activities offered at NHs. Table 1 provides an overview of responses regarding individuals' perceived changes in their social skills and their ability to relate to a community setting. The survey is based on a random sample of 675 respondents from $14 \mathrm{NHs}$ comprising Canadian- and foreign-born users (65\% newcomers; $77 \%$ women; $54 \%$ employed; $30 \%$ university degree).

The results of this survey shed light on the capacity building of a community-based organization such as $\mathrm{NHs}$ (Larcombe, 2008) both at the individual and the collective level. At the individual level, NHs prove to be valuable sites for the formation of social capital in the sense that Putnam (2000, p. 19) used the term as "connections among individuals' social networks and the norms of reciprocity and trustworthiness that arise from them."

\footnotetext{
${ }^{1}$ The research results are based on the four year project Neighbourhood Houses in Metro Vancouver, funded by the Social Sciences and Humanities Council of Canada (lead: Miu Chung Yan, UBC). We conducted an analysis of all $14 \mathrm{NHs}$ in the lower mainland and would like to thank them for their time and support of our research; for more detailed results of this research see the project website: www.nhvproject.ca and Yan and Lauer (forthcoming).
} 
Table 1. Perceived changes in social skills through involvement at NHs.

\begin{tabular}{llllllll}
\hline (\%) & & & \multicolumn{3}{c}{ Place of Birth } \\
\hline $\begin{array}{l}\text { Change in social skills due to involvement } \\
\text { in NHs }\end{array}$ & $\begin{array}{l}\text { Increased } \\
\text { a little }\end{array}$ & $\begin{array}{l}\text { Increased } \\
\text { a lot }\end{array}$ & $\begin{array}{l}\text { Increased } \\
\text { a little }\end{array}$ & $\begin{array}{l}\text { Increased } \\
\text { a lot }\end{array}$ & $\begin{array}{l}\text { Increased } \\
\text { a little }\end{array}$ & $\begin{array}{l}\text { Increased } \\
\text { a lot }\end{array}$ \\
\hline $\begin{array}{l}\text { Has your ability to work with people from } \\
\text { different backgrounds changed? }\end{array}$ & 42 & 34 & 34 & 29 & 46 & 38 \\
$\begin{array}{l}\text { Have your decision-making abilities } \\
\text { changed? }\end{array}$ & 42 & 26 & 30 & 19 & 48 & 29 \\
\hline $\begin{array}{l}\text { Have your skills in organizing or managing } \\
\text { events and programs changed? }\end{array}$ & 36 & 21 & 24 & 17 & 42 & 23 \\
$\begin{array}{l}\text { Have your skills in speaking in front of } \\
\text { other people changed? }\end{array}$ & 35 & 27 & 22 & 19 & 42 & 32 \\
\hline
\end{tabular}

Based on the self-assessment of the participants, NHs create the capacity to engage with others in the community and to develop skills to do this in a meaningful and competent way. This empowerment of immigrants and members of the minority community is also facilitated by simple facts. For instance, all NHs operate in a multilinguistic environment (with a majority of employers being bilingual) and one is widely run by immigrants and minorities themselves.

In this regard, the seemingly mundane practice of interacting at $\mathrm{NHs}$ and participating in community-based activities can allow for the learning and practice of important civic and political skills. The effect on the skills and confidence of the respondents is particularly pronounced for those born outside of the country. The local community at the NH validates and recognizes a person's contributions. These civic skills learned through the experience of involvement and relating to others are a pivotal resource that contributes to overcoming social isolation and to encouraging engagement in the wider community. In a survey of 687 users, ${ }^{2}$ we found a significant increase in civic and community engagement directly related to being involved in NHs. Similarly, qualitative interviews with this group underlined that social isolation is a major concern and one that can effectively be addressed by $\mathrm{NHs}$. For instance, over $60 \%$ of respondents stated that they made at least one close friend through the NHs.

One critical way in which immigrants and minorities find themselves isolated and unable to contribute to public debates is the absence of low-threshold opportunities for engagement. NHs offer precisely this entry into communal engagement in a non-threatening, service-based environment. The project conducted oral histories with participants about their personal experiences of NHs. One recurrent theme in these interviews is how the use of services gradually built trust and turned NHs into 'safe places' (for a detailed account of these findings see: Yan \& Lauer, forthcoming). Instrumental in this respect is also
NHs' reliance on volunteers; in 2012-2013, over 3670 people registered as volunteers in NHs in Metro Vancouver. In the same vein, $\mathrm{NH}$ s have become socializing agencies that regularly allow immigrants to become leaders in their community and to take on prominent roles in public life. In 2013, over $60 \%$ of staff members at NHs were either current or former resident service users. As an active part of the NGO community at the urban level, NHs provide ample opportunity for paving the path towards professional careers with third sector organizations, community engagement, and leadership.

At the collective level, NHs facilitate residents working together to achieve collective goals. NHs provide a physical and social framework for social networks, dialogue, and collective-communal empowerment. The skills that community members acquire in taking part in or organizing events can easily be transferred to other forms of active engagement. Through low-cost, familyfriendly services and social events, NHs offer tangible incentives to overcome the alienation from communal life in particular for those who have a more precarious social status (low income, seniors, immigrants/ minorities). These self-governed community associations can be interpreted as entry points and networks facilitating democratic participation in a basic, yet essential way. As Yan (2004, p. 58) puts it, "motives of democratic participation, sharing, and reciprocity are actualized through services" offered at NHs (e.g., Yan \& Lauer, 2008).

The results of the survey provide us with an interpretative lens into the broader socio-political function that such civil society associations can take on in giving a voice to newcomers and minorities. By investigating the role that NHs play in municipal and provincial policymaking, our research found consistent evidence of how these self-governed associations in Greater Vancouver establish an institutional infrastructure for building and strengthening urban communities and nurturing their collective capacity. The case study of $\mathrm{NHs}$ emphasizes

\footnotetext{
2 For a summary of these findings see the research brief by Sean Lauer ay http://nhvproject.ca/wp-content/uploads/2016/12/7.-Civic-and-CommunityEngagement-Survey-findings.pdf
} 
the importance of bridging social capital-establishing vertical social networks between socially diverse groups or organizations. The role of these organizations in the urban context shows that, when previously unrelated or dissimilar community organizations and groups connect with one another, the created ties strengthen the overall social fabric (e.g., Gittell \& Vidal, 1998). For instance, one prominent initiative of the Mount Pleasant NH is the support of a food network (http://www.mpnh.org/food), which has led the collaboration of a host of stakeholders such as community groups, NGOs, and city administrators. Thus, bridging social capital also expands the possibilities for inter-sectoral collaboration.

It became clear in our interviews with the NHs' executive directors that it is a contested idea whether and to what degree NHs have a mandate to be a political advocate of the community. However, in practice, NHs have proven to be instrumental both as a vehicle for community engagement and as a partner for NGOs and policy-makers primarily at the municipal level. In Vancouver, NHs have established themselves as critical for effective policy initiatives and implementation, or as one director put it, NHs are the "eyes and ears in the community." ${ }^{3}$ In practice, the border between political advocacy groups and networks of professionals can become blurred concerning the circle of activists and targets of public campaigns.

Their position in driving the integration agenda is centrally linked to the $\mathrm{NHs}^{\prime}$ role as catalysts for community collaboration. In one of our focus group sessions, an NGO representative stated:

What the NHs have done for us is sort of allow us to network with the community, and brought us into projects that we wouldn't necessarily have been involved in.....And how we, as an organization...can provide assistance or help or advocate as partners at City Hall when we need to advocate for certain things. When we are trying to advocate for certain things, they come and support us. ${ }^{4}$

NHs are the hub of an extensive service network through which untapped community assets are mobilized and nurtured.

In this respect, NHs are an integral part of "placebased" governance in Metro Vancouver. As our interviews and focus groups underline, NHs are in an ideal position to provide an institutional capacity for community governance, to foster mutual learning among community members, and to permit community input and direction in the development and implementation of integration programs. In Metro Vancouver, NHs have established themselves as a critical link between the people, governments, and private stakeholders that make up communities. NHs provide social infrastructures and networks of democratic participation, thereby giving voice to those who often feel alienated from government processes. The focus groups and interviews with staff persistently highlighted the role of $\mathrm{NHs}$ as a forum for community-based governance, and as an important twoway conduit between community members and the different levels of government.

Even though it is difficult to stipulate the kind of impact that migrant organizations have on public policy formation, I argue that the local and regional levels have generated some marked opportunities for civil society input and initiatives. In this respect, immigrant or minority communities gain-as Winders (2012) puts it in his study on urban politics in the US- "institutional visibility" in local contexts, thereby allowing them to make political claims. The growing incorporation of immigrants into the political process at the local level has a marked effect on political framing and the institutional logics on which policy formation is based. One could speak about a circulus virtuosus set in motion by mainstreaming immigrant integration into the practices of public administration and governance structures. The inclusion of immigrant organizations into program design and policy formation can lead to institutional learning processes and, as an effect, better service provision. This process in turn is likely to strengthen the willingness to see immigrants and minorities included into the deliberation and, in some cases, decision-making procedures regarding integration programs and policies (e.g., Caponio \& Borkert, 2010; Scholten, 2013).

\section{Canada's Private Sponsorship of Refugees Program: Community Mobilization}

Another dimension of how Canada governs immigration speaks to how the communal inclusion and participation of newcomers is built into Canada's refugee policies. In the following section, I shed light in particular on Canada's Private Sponsorship of Refugees (PSR) program and its societal and political effects. The concept of immigrant and refugee sponsorship was first introduced in Canada in the late 1970s as a provision within the Immigration Act. The Act, signed and adopted in 1976, put into place specifications which allowed groups of five or more individuals to sponsor immigrants or refugees privately (Lanphier, 2003). Based on revisions introduced in the Immigration and Refugee Protection Act (IRPA) in 2002, there are various tracks in Canada's refugee policy; the two most important ones are the GovernmentAssisted Refugee (GAR) and the PSR programs. Each of these programs provides refugees with settlement support and services for one year. This support structure is either offered through designated non-governmental service provider organizations or through the network of private citizens who raise the resources and provide assistance independent of state institutions (e.g., Hyndman, Payne, \& Jimenez, 2017; Simich, 2003).

\footnotetext{
${ }^{3}$ Interview conducted at Collingwood NH, March 2015.

${ }^{4}$ Focus group conducted on September 14, 2014 in Vancouver.
} 
Over the past decade, Canada has vastly expanded the number of refugees that are resettled in Canada through the PSR program (see Figure 1). This process has led to criticism of the PSR program as an attempt to delegate and download responsibility for refugees and asylum seekers from the state to civil society. It is not by accident that this shift in how refugees resettle in Canada has happened mainly under the neoliberal auspices of the Conservative government led by Prime Minister Harper (e.g., Silvius, 2016).

However, rather than discussing the driving forces behind the expansion of the PSR program and its meaning in the wider transformation of Canada's immigration policies, this article focuses on the-unintendedeffects that PSR has had on the societal integration of refugees. Considering the interest in the transformative power of migrants, I concentrate on three different dimensions of the broader socio-political implications that the PSR program has had: a) the effects on the integration of refugees; $b$ ) the mobilization of community networks and resources (horizontal networking), and c) the political impact on the broader public debate and policymaking related to refugees.

\subsection{The Effects on the Integration of Refugees}

While not conceptualized as its primary objective, the PSR program has had a remarkable effect on the settlement and long-term integration experience of refugees in Canada. Different from their peers in the state-sponsored track, refugees that can rely on a group of sponsors immediately have access to a robust support network in the local community. There is a strong consensus among scholars and practitioners that the program has been largely successful in supporting refugee integration (e.g., Beiser, 2003; Lenard,
2016). For instance, Krivenko (2016) demonstrates how the PSR program has proven effective in linking newcomer refugees with the community and social structures of the receiving country. These networks prove to be instrumental in promoting language acquisition, employment, and the broader familiarity with public-administrative life in the receiving country. Based on these experiences, Krivenko suggests that the PSR program provides valuable lessons for broader integration policies, such as accessing the local community, building social capital, and connecting refugees to the full array of services available to them.

In the past there has been criticism about the effectiveness of PSR program concerning the promotion of the integration of refugees. For example, a 1989 study of the experiences of privately sponsored Southeast Asian individuals and families in Canada found that refugee newcomers often felt over-protected by sponsors, and many expressed frustration with regards to the inequity of support provided across sponsorship groups (Beiser, Turner, \& Ganesan, 1989). Arguably the most significant criticism addresses the concern that privately sponsored refugee newcomers tended to have minimal interaction with individuals outside of their own ethnic group in those cases in which the sponsorship group is composed of members of the refugee's ethnocultural group. The lack of interaction proved to be a particular challenge during the period in which Canada received high numbers of Vietnamese refugees in the late 1970 s. Also, the PSR program is regularly under scrutiny regarding whether Canadian sponsor groups are overly assimilationist in imposing their cultural, social, and, in some cases, religious conventions on refugee newcomers and their families (Lanphier, 2003).

Overall, having private citizens raise funds needed for sponsoring refugees for one year and assisting them

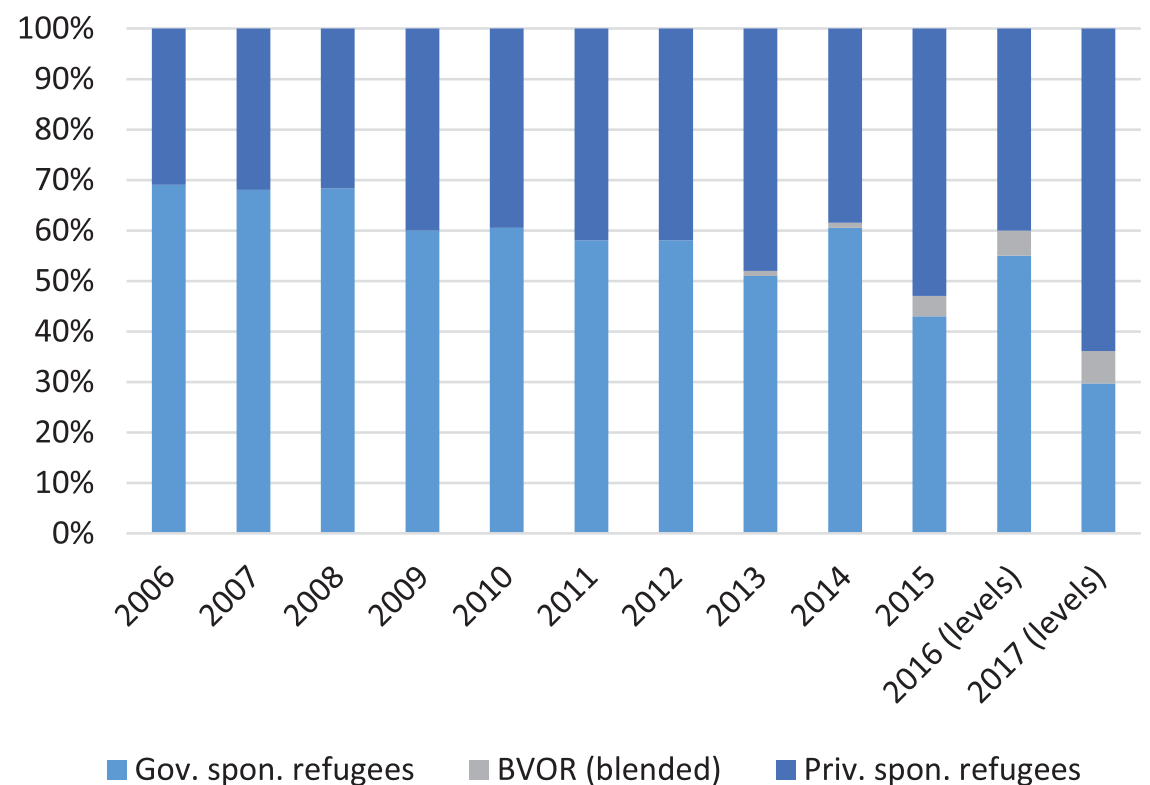

Figure 1. Resettled refugees (2006-2017). 
in their settlement efforts can be seen as highly effective in promoting integration efforts. A recent Immigration, Refugees and Citizenship Canada (IRCC) evaluation of both the PSR and the GAR program sheds light on remarkably divergent integration outcomes. ${ }^{5}$ For instance, five years after landing in Canada, $41 \%$ of GAR relied on social assistance, compared to just $28 \%$ among those sponsored by private groups. Similarly, those refugees that came through the GAR program had markedly lower employment rates and employment earnings (see Figure 2). A host of factors contribute to the difference in outcomes among the two groups, unquestionably including demographic aspects like levels of education, linguistic proficiency, and country of origin. Yet, research has underlined that access to settlement services and broader community integration also plays a central role (e.g., Wilkinson \& Garcea, 2017). Analyzing the results for the recent arrival of tens of thousand of refugees from Syria, the IRCC report underlines how critical the support and guidance offered by sponsorship groups have been for success on the labour market, the educational system or societal integration more broadly. The following graph (Figure 2) illustrates the dramatic difference in employment rates of resettled refugees in their first year and the eventual evening out of this difference after 10 years.

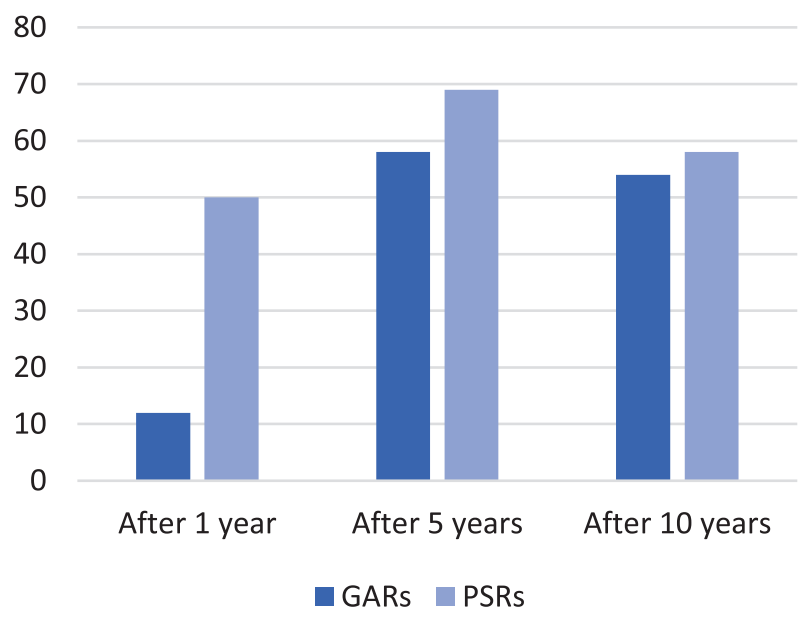

Figure 2. Employment rates of resettled refugees in Canada (2002-2012).

\subsection{The Mobilization of Community Networks and Resources (Horizontal Networking)}

The success in promoting the settlement and integration of refugees through the private sponsorship program can, at its core, be attributed to how these small groups mobilize community resources and play a central role in linking these newcomers to communal life at large. It is commonly a defining feature of sponsorship groups that its members use their links into the community as bridges for refugees and empower them through these network of stakeholders and organiza- tions. Ives (2007) and Soroka, Johnston and Banting (2007) have recognized that building strong social networks and bridging diverse communities are essential steps in the integration process. Indeed, urban contexts addressing the issue of settling refugees have become sites for facilitating partnerships and modes of cooperation between government agencies and civil society groups (Biles, 2008, pp. 163-66). Bowen, NewenhamKahindi and Herremans (2010) stress the importance of community engagement for municipal administrations, businesses and other community groups to bolster support and legitimacy (Bowen et al., 2010, pp. 303-305).

\subsection{The Political Impact on the Broader Public Debate and Policy-Making Related to Refugees}

The way in which the PSR program, in particular, relies on and engages with the civil society stakeholders also generates a particular political effect. It is through connecting refugees with community members, informing the public (for instance through fundraising or social events), and drawing attention to the broader issue of refugees that the private sponsorship program often promotes important multipliers in the community. Over 275,000 refugees have been sponsored by PSR since its inception about forty years ago. On average sponsorship groups have about ten members which indicates how strong the humanitarian commitment of civil society is and how far reaching the effects of the program are likely to be. This dynamic, generated primarily through local networks and civil society communities, proved to be a major factor in Canada's response to the global refugee crisis. In the 2015 federal elections, the governing Conservative Party under Stephen Harper decided to keep the numbers for resettled refugees very low despite the mounting urgency to address the effects of the Syrian civil war. Canada's commitment to addressing the suffering of the refugees became a critical public debate during the electoral campaign. It would be difficult to understand the intense public pressure demanding a greater intake of refugees without the networks built collaboratively with refugees on the ground. In this respect, the PSR program has considerable socializing (and educational) effects. By providing community-based services and support, the sponsor groups create meaningful arenas for engaging with refugees and the wider community addressing responses to the global refugee crisis.

Regarding the broader socio-political implications of the PSR program, there is a remarkable difference between the Canadian and large parts of the European context. Canada has widely been immune to the antiimmigrant sentiments and resurgent populist nationalism. Clearly, this development is driven by the dynamic of the country's system of competitive politics and the way in which almost 50 years of official multiculturalism has changed the political landscape (Banting, Courchene, \& Seidle, 2007). One critical element in this con-

\footnotetext{
${ }^{5}$ See for the report Government of Canada (2016).
} 
text is how issues of migration and diversity are politicized and addressed in policy terms. The recent response to the global refugee crisis is a case in point: The issue was primarily debated in terms of Canada's capacity on the ground and the pragmatic challenges that the influx of a large number of refugees would pose. Largely absent was the dramatic, identity-centred discourse that the populist right mobilized in many countries of Europe (Schmidtke, 2015). One key factor that is likely to account for the different logic of politicizing issues of integration and developing policy responses might be Canada's more articulate forms of political inclusion and advocacy at this level of governance. The relative strength of civil society actors and their-partial-inclusion into the political and policy process is likely to produce a less nationalistpopulist and a more pragmatic approach.

\section{Conclusions: The Transformative Power of Vibrant Local Communities}

In the Canadian context, civil society based engagement with immigrants and refugees has created a particular socio-political dynamic promoting effective integration. While the state-driven multiculturalism and integration policies have provided the national framework for governing diversity and including newcomers, local actors and networks account for how these processes unfold on the ground. It is one of the striking features of the Canadian context that, particularly in urban settings, immigrants have gained agency and voice in the public arena through a web of civil society interactions. The Canadian case provides compelling evidence of the power of placebased, community-driven modes of shaping integration and providing newcomers and minorities with real opportunities for engagement and empowerment.

The effects of these networks are twofold concerning the research questions raised in this article: First, providing agency and voice to newcomers and minorities through engagement at the local level gives substance to the regular claim that 'integration' should be based on a two-way interactional process between a host society and newcomers. Immigrants are not simply the objects of the demand for successful integration; rather, they participate in deliberating its meaning and evolving societal practices. There is a sense of agency for immigrants and minorities that emerges out of community-based institutional practices and interactions. In particular, the local level has become an arena for negotiating the meaning of what cultural diversity and successful 'integration' means on the ground. Evidence from both of the empirical cases illustrated here (NHs and PSRs) suggest that the participation in the local governance structure is itself a critical dimension of (political) inclusion as well as a mode of facilitating effective integration more broadly.

Second, this form of participatory inclusion affects the majority culture, its perception of immigrants, and the associated politics of migration. Providing migrants with agency and voice generates a specific political dy- namic in governing immigration and cultural diversity. The participatory mode of engaging migrants and their full inclusion across the political system has created its own self-reinforcing logic: The more newcomers and minorities find access to public arenas of deliberation, the more difficult it becomes to exploit this group for purposes of political mobilization driven by anti-immigrant sentiments. The broad consensus in Canadian society that immigration and equitable integration are desirable is partly rooted in the ways in which immigrants and minorities have shaped civil society practices. To a substantial degree, this dynamic has immunized Canadian politics to the rhetoric of nationalist exclusion that has taken hold of many liberal democracies.

\section{Acknowledgments}

I would like to acknowledge the support provided by the Social Sciences and Humanities Council of Canada (SSHRC); the findings of this article are partly based on the project Neighbourhood Houses in Metro Vancouver that was funded by SSHRC.

\section{Conflict of Interests}

The author declares no conflict of interests.

\section{References}

Ager, A., \& Strang, A. (2008). Understanding integration: A conceptual framework. Journal of Refugee Studies, 21(2), 166-191.

Banting, K., Courchene, T., \& Seidle, L. (Eds.) (2007). Belonging? Diversity, recognition and shared citizenship in Canada. Montreal: Institute for Research on Public Policy.

Beiser, M. (2003). Sponsorship and resettlement success. Journal of International Migration and Integration, 4(2), 203-215.

Beiser, M., Turner, R. J., \& Ganesan, S. (1989). Catastrophic stress and factors affecting its consequences among Southeast Asian refugees. Social Science and Medicine, 28(3), 183-195.

Bertossi, C., \& Duyvendak, J. W. (2012). National models of immigrant integration. The costs for comparative research. Comparative European Politics, 10(3), 237-247.

Biles, J. (2008). Integration policies in English-speaking Canada. In J. Biles, M. Burstein, \& J. Frideres (Eds.), Immigration and integration in Canada in the twentyfirst century (pp. 139-86). Kingston: Queen's University, School of Policy Studies.

Bloemraad, I., Korteweg, A., \& Yurdakul, G. (2008). Citizenship and immigration: Multiculturalism, assimilation, and challenges to the nation-state. Annual Review of Sociology, 34, 153-179. doi:10.1146/ annurev.soc.34.040507.134608

Bowen, F., Newenham-Kahindi, A., \& Herremans, I. 
(2010). When suits meet roots: The antecedents and consequences of community engagement strategy. Journal of Business Ethics, 95(2), 297-318.

Bradford, N. (2005). Place-based public policy: Towards a new urban and community agenda for Canada. Ottawa: Canadian Policy Research Networks.

Brubaker, R. (2001). The return of assimilation? Changing perspectives on immigration and its sequels in France, Germany, and the United States. Ethnic and Racial Studies, 24(4), 531-548.

Caponio, T., \& Borkert, M. (Eds.) (2010). The local dimension of migration policymaking. Amsterdam: Amsterdam University Press.

Citizenship and Immigration Canada. (2001). Immigrant integration in Canada: Policy objectives, program delivery and challenges. Ottawa: $\mathrm{CIC}$, Immigration Branch.

Duyvendak, J. W., \& Scholten, P. (2011). Beyond the Dutch 'multicultural model': The coproduction of integration policy frames in the Netherlands. International Migration and Integration, 12(3), 331-348.

Entzinger, H., \& Biezeveld, R. (2003). Benchmarking in immigrant integration. Rotterdam: European Research Centre on Migration and Ethnic Relations.

Erdal, M. B., \& Oeppen, C. (2013). Migrant balancing acts: Understanding the interactions between integration and transnationalism. Journal of Ethnic and Migration Studies, 39(6), 867-884.

Esser, H. (2010). Assimilation, ethnic stratification, or selective acculturation? Recent theories of the integration of immigrants and the model of intergenerational integration. Sociologica, 4(1), 110-135.

Falge, C., Ruzza, C., \& Schmidtke, O. (2012). Giving new subjects a voice. Political and institutional responses to cultural diversity in the health care system. Aldershot: Ashgate.

Freeman, G. P. (2004). Immigrant incorporation in Western democracies. International Migration Review, 38(3), 945-969.

Gittell, R., \& Vidal, A. (1998). Community organizing: Building social capital as a development strategy. Thousand Oaks, CA: Sage Publications.

Government of Canada. (2016). Evaluation of the resettlement programs (GAR, PSR, BVOR and RAP). Retrieved from http://www.cic.gc.ca/english/ resources/evaluation/resettlement.asp

Habermas, J. (1996). Die Einbeziehung des Anderen. Studien zur politischen Theorie. Frankfurt: Suhrkamp.

Hepburn, E. (2011). 'Citizens of the region': Party conceptions of regional citizenship and immigrant integration. European Journal of Political Research, 50(4), 504-529.

Hiebert, D., \& Sherrell, K. (2009). The Integration and inclusion of newcomers in British Columbia (Working Paper No. 2009-11). Vancouver: Metropolis British Columbia.

Hyndman, J., Payne, W., \& Jimenez, S. (2017). Private refugee sponsorship in Canada. Forced International
Migration and Integration, 4(2), 237-256.

Ives, N. (2007). More than a "good back": Looking for integration in refugee resettlement. Refuge, 24(2), 54-63.

Jacobs, D., \& Rea, A. (2007). The end of national models? Integration courses and citizenship trajectories in Europe. International Journal on Multicultural Societies, 9(2), 264-283.

Joppke, C. (2007). Beyond national models: Civic integration policies for immigrants in Western Europe. West European Politics, 30(1), 1-22.

Joppke, C., \& Morawska, E. (Eds.). (2014). Integrating immigrants in liberal nation-states: Policies and practices. London: Palgrave Macmillan.

Krivenko, E. Y. (2016). The private sponsorship of refugees: A key agenda for integration. Policy Options, 17.

Lanphier, M. (2003). Sponsorship: Organizational, sponsor, and refugee perspectives. Journal of International Migration and Integration, 4(2), 237-256.

Larcombe, K. (2008). Community capacity building: A role for neighbourhood houses in community revitalization (Unpublished doctoral dissertation). Vancouver: University of British Columbia, Canada.

Lenard, P. T. (2016). Resettling refugees: Is private sponsorship a just way forward? Journal of Global Ethics, 12(3), 300-310.

Leo, C., \& August, M. (2009). The multilevel governance of immigration and settlement: Making deep federalism work. Canadian Journal of Political Science, 42(2), 491-510.

Ley, D. (2007). Post multiculturalism? In L. Hanley, B. Ruble, \& A. Garland (Eds.), Immigration and integration in urban communities: Renegotiating the city (pp. 177-97). Washington, DC: Woodrow Wilson International Center Press.

Li, P. S. (2003). Deconstructing Canada's discourse of immigrant integration. Journal of International Migration and Integration, 4(3), 315-333.

Parekh, B. (2006). Rethinking multiculturalism: Cultural diversity and political theory. New York: Palgrave Macmillan.

Penninx, R., Kraal, K., Martiniello, M., \& Vertovec, S. (Eds.). (2004). Citizenship in European cities. Immigrants, local politics and integration policies. Aldershot: Ashgate.

Putnam, R. D. (2000). Bowling alone: The collapse and revival of American community. New York: Simon \& Schuster.

Schmidtke, O. (2014). Managing migration and diversity in Canada and Germany: Beyond national models. Comparative Migration Studies, 2(1), 77-99.

Schmidtke, O. (2015). Between populist rhetoric and pragmatic policy making: The normalization of migration as an electoral issue in German politics. Acta Politica, 50, 379-398.

Scholten, P. W. A. (2013). Agenda dynamics and the multi-level governance of intractable policy contro- 
versies: The case of migrant integration policies in the Netherlands. Policy Sciences, 46(3), 217-236.

Siemiatycki, M. (2012). The place of immigrants: Citizenship, settlement, and socio-cultural integration in Canada. In D. Rodriguez-Garcia (Ed.), Managing immigration and diversity in Canada. A transatlantic dialogue in the new age of migration (pp. 223-247). Montreal and Kingston: McGill-Queens University Press.

Silvius, R. (2016). Neo-liberalization, devolution, and refugee well-being: A case study in Winnipeg, Manitoba. Canadian Ethnic Studies, 48(3), 27-44.

Simich, L. (2003). Reinforcing refugee resettlement: An introduction to private sponsorship and partnerships. Journal of International Migration and Integration, 4(2), 153-156.

Soroka, S. N., Johnston, R., \& Banting, K. (2007). Ties that bind? Social cohesion and diversity in Canada. In K. Banting, T. J. Courchene \& F. L. Seidle (Eds.), Belonging? Diversity, recognition and shared citizenship in Canada (pp. 561-600). Montreal: Institute for Research in Public Policy.

Stasiulis, D., Hughes, C., \& Amery, Z. (2011). From government to multilevel governance of immigrant settlement in Ontario's city-regions. In E. Tolley \& R. Young (Eds.), Immigrant settlement policy in Canadian municipalities (pp. 73-147). Montreal and Kingston: McGill-Queen's University Press.

Tossutti, L. S. (2012). Municipal roles in immigrant set- tlement, integration and cultural diversity. Canadian Journal of Political Science, 45(3), 607-633.

Triadafilopoulos, T. (2011). Illiberal means to liberal ends? Understanding recent immigrant integration policies in Europe. Journal of Ethnic and Migration Studies, 37(6), 861-880.

Triadafilopoulos, T. (2012). Becoming multicultural. Immigration and the politics of membership in Canada and Germany. Vancouver: University of British Columbia Press.

Wilkinson, L., \& Garcea, J. (2017). The economic integration of refugees in Canada: A mixed record? Migration Policy Institute.

Winders, J. (2012). Seeing immigrants: Institutional visibility and immigrant incorporation in new immigrant destinations. Annals of the American Academy of Political \& Social Science, 641(1), 58-78.

Yan, M. C. (2004). Bridging the fragmented community: Revitalizing settlement houses in the global era. Journal of Community Practice, 12(1/5), 51-68.

Yan, M. C., \& Lauer, S. (2008). Social capital and ethnocultural diverse immigrants: A Canadian study on settlement house and social integration. Journal of Ethnic \& Cultural Diversity in Social Work, 17(3), 229-249.

Yan, M. C., Lauer, S. (Eds.). (forthcoming). A placebased solution to urban disconnection: Neighbourhood houses in Metro Vancouver. Vancouver: UBC Press.

\section{About the Author}

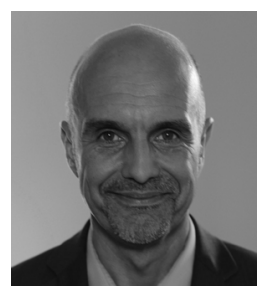

Oliver Schmidtke is a Professor in the Departments of Political Science and History at the University of Victoria where he also holds the Jean Monnet Chair in European History and Politics. He currently serves as the director of the Centre for Global Studies in Victoria. His research interests are in the fields of the political sociology and politics of migration, citizenship, nationalism, and the governance of migration and integration in Europe and Canada. 